\title{
EFFECT OF THE COOLING RATE ON PHASE TRANSFORMATIONS IN A SURFACE-ALLOYED LAYER OF STEEL
}

\author{
Ivanov Yu. ${ }^{1}$, Klopotov A. ${ }^{2}$, Teresov A. ${ }^{1}$, Petrikova E. ${ }^{1}$, Shugurov V. ${ }^{1}$, Song G. ${ }^{3}$, Tang G. ${ }^{3}$, Gromov V. ${ }^{4}$ \\ ${ }^{1}$ Institute of High Current Electronics, the Siberian Branch of the Russian Academy of Sciences, Tomsk, Russia \\ ${ }^{2}$ Tomsk State University of Architecture and Building, Tomsk, Russia \\ ${ }^{3}$ Tsinghua University, Shenzhen, China \\ ${ }^{4}$ Siberian State Industrial University, Novokuznetsk, Russia
}

Abstract. Surface alloying of AISI 420 steel was carried out in a single vacuum cycle, and consisted of spraying a thin $(0.5 \mu \mathrm{m})$ film of $\mathrm{Zr}$-Ti-Cu alloy by electric arc spraying of a cathode of the composition $\mathrm{Zr}-6$ at. $\%$ Ti- 6 at. $\% \mathrm{Cu}$, and the subsequent irradiation of the "film (Zr-Ti-Cu alloy) / (AISI 420 steel) substrate" system with an intense pulsed electron beam. It is shown that the concentration of zirconium in the surface layer of steel decreases with an increase in the energy density of the electron beam $\left(E_{S}\right)$. It is established that formation of a surface alloy is accompanied by the following: formation of a cellular crystallization structure (the average cell size increases from $150 \mathrm{~nm}$ at $\mathrm{E}_{\mathrm{S}}=20 \mathrm{~J} / \mathrm{cm}^{2}$ to 370 $\mathrm{nm}$ at $\mathrm{E}_{\mathrm{S}}=40 \mathrm{~J} / \mathrm{cm}^{2}$ ); decomposition of a solid solution with the release of zirconium carbide particles (particle sizes increase from (10-15) nm at $E_{S}=20 \mathrm{~J} / \mathrm{cm}^{2}$ to $(30-40) \mathrm{nm}$ at $\left.E_{\mathrm{S}}=40 \mathrm{~J} / \mathrm{cm}^{2}\right)$. Particles of the carbide phase based on chromium of the composition $\mathrm{Cr}_{3} \mathrm{C}_{2}, \mathrm{Cr}_{7} \mathrm{C}_{3}$ and $(\mathrm{Cr}, \mathrm{Fe})_{23} \mathrm{C}_{6}$, along with zirconium carbide particles, are revealed upon the irradiation of the "film ( $\mathrm{Zr}-\mathrm{Ti}$-Cu alloy) / (AISI 420 steel) substrate" system with an intense pulsed electron beam $\left(E_{S}=40 \mathrm{~J} / \mathrm{cm}^{2}\right)$. Chromium carbide particles have a round shape; their sizes vary from $40 \mathrm{~nm}$ to $60 \mathrm{~nm}$. The authors analyzed phase transformation diagrams taking place under equilibrium conditions in $\mathrm{Fe}-\mathrm{Zr}-\mathrm{C} ; \mathrm{Cr}-\mathrm{Zr}-\mathrm{C} ; \mathrm{Fe}-\mathrm{Cr}-\mathrm{Zr}$ systems. It is established that ultra-high cooling rates that occur during the irradiation of the "film (Zr-Ti-Cu alloy) / (AISI 420 steel) substrate" system with an intense pulsed electron beam impose limitations on the formation of phases of the intermetallic type. It is assumed that the formation of predominantly carbide phases in the surface layer of the material is due to high mobility of carbon atoms in steel.

Keywords: AISI 420 steel, electron beam processing, structure, phase composition.

\section{Introduction}

Formation of surface alloys is one of the methods for substantial improvement of the structure of parts and products, as well as an increase in their service life. This approach avoids the use of expensive, highly alloyed materials which require significant financial and energy costs, both during the production and processing of parts and products. A promising method for formation of surface alloys is the combined treatment, which includes the deposition of thin films of alloying elements and the subsequent irradiation with concentrated energy fluxes (laser radiation [1, 2], high-intensity electron [3-5] and powerful ion $[6,7]$ beams, plasma flows and jets [8-11]). A vacuum-arc method based on the generation of highly-ionized metal plasma flows with an arc discharge is often used for deposition of films $[12,13]$. Coatings are formed as a result of condensation of plasma flow of the eroding cathode material on the sample surface. Almost any metal, alloy, or metal-based composite can act as a cathode material. The high degree of vacuum arc plasma

(c) Ivanov Yu., Klopotov A., Teresov A., Petrikova E., Shugurov V., Song G., Tang G., Gromov V., 2019 ionization $(20-100) \%$ and the ability to adjust the parameters of the coating synthesis process over a wide range (working gas pressure, discharge current, bias voltage, etc.) allows to regulate the elemental composition and the structure of condensates [12].

The purpose of this paper is to analyze phase transformations taking place during surface doping of steel with an intense pulsed electron beam.

\section{Material and research methods}

Samples of high-chromium steel AISI420 (0.25 C, $13 \mathrm{Cr}, 0.6 \mathrm{Si}, 0.6 \mathrm{Mn}, 0.6 \mathrm{Ni},<0.025 \mathrm{~S} ;<0.03 \mathrm{P}$, remaining $\mathrm{Fe}$, wt $\%$ ) were chosen as a material of the study [14]. The samples had the plate-like shape with the dimensions of $15 \times 15 \times 5 \mathrm{~mm}$. Complex modification of the structure and properties of AISI420 steel samples was carried out on the laboratory installation "COMPLEX", developed and manufactured at the Institute of High Current Electronics, Siberian Branch of the Russian Academy of Sciences (ISE SB RAS) [15]. The first stage of modification included formation of a metallic film on the surface of steel samples as a result of condensation of plasma flow of the eroding cathode material. The cathode of the composition Zr-5 ат. \% Ti5 aт. $\% \mathrm{Cu}$, manufactured using methods of powder 
metallurgy, was used as the spray material. Second stage included the irradiation of the system "film (Zr-Ti-Cu alloy) / (AISI420 steel) substrate" with an intense pulsed electron beam under the following parameters: electron energy was $17 \mathrm{keV}$; energy density of the electron beam was $(20-40) \mathrm{J} / \mathrm{cm}^{2}$; pulse duration of the electron beam was $200 \mu$ s; repetition rate and the number of pulses was $0.3 \mathrm{~s}^{-1}$ and 3 , respectively. The elemental and phase composition, and the state of the defective substructure of the modified surface were analyzed using methods of scanning (device SEM-515 "Philips") and transmission (device EM-125) electron microscopy.

\section{Results and discussion}

The main elements of the surface-doped layer are $\mathrm{Fe}, \mathrm{Cr}, \mathrm{Zr}$, and C. Based on the study of the phase diagrams of $\mathrm{Fe}-\mathrm{Cr}-\mathrm{Zr}, \mathrm{Cr}-\mathrm{Zr}-\mathrm{C}$, and $\mathrm{Fe}-\mathrm{Cr}-\mathrm{C}$ systems obtained under equilibrium conditions we shall analyze phase transformations in the given alloy.

System $\mathrm{Zr}-\mathrm{Cr}-\mathrm{C}$. Binary diagrams and the isothermal section of the ternary diagram of the system $\mathrm{Zr}-\mathrm{Cr}-\mathrm{C}$ at a temperature of $1300^{\circ} \mathrm{C}$ are shown in Fig. 1 [16]. Formation of a large number of binary compounds as well as a ternary compound based on the binary compound $\mathrm{Zr}_{\mathrm{X}} \mathrm{C}_{1-\mathrm{X}}$ with a limited homogeneity region is possible in this system. The ternary system $\mathrm{Zr}-\mathrm{Cr}-\mathrm{C}$ is characterized by the absence of single-phase regions of ternary compounds of the type $\mathrm{C}_{1-\mathrm{X}} \mathrm{Cr}_{1-\mathrm{y}} \mathrm{Zr}_{\mathrm{X}+\mathrm{y}}$ within the isothermal triangle.

System $\mathrm{Fe}-\mathrm{Zr}-\mathrm{C}$. Binary diagrams and the isothermal section of the ternary diagram of the system $\mathrm{Fe}-\mathrm{Zr}-\mathrm{C}$ are shown in Fig. 2. This system is characterized by formation of binary compounds only [17].

System $\boldsymbol{C r}-\mathbf{F e}-\mathbf{Z r}$. In the system $\mathrm{Cr}-\mathrm{Fe}-\mathrm{Zr}$ (Fig. 3), ternary compounds based on binary compounds begin on two sides of the isothermal triangle $\mathrm{Fe}-\mathrm{Zr}$ and $\mathrm{Cr}-\mathrm{Zr}$ in the form of wide homogeneity regions with stoichiometric compositions $\mathrm{ZrFe}_{2}$ (Laves phase with a structure $\mathrm{C} 15$ ) and $\mathrm{ZrCr}_{2}$ (Laves phase with the structure of C14), respectively [18, 19]. An extended region of the existence of a ternary compound inside the isothermal triangle $\gamma-\mathrm{Zr}(\mathrm{Cr}$, $\mathrm{Fe})_{2}$ with the Laves phase structure $\mathrm{C} 14$ has been established. This compound is conjugated to two ternary compounds based on $\mathrm{ZrFe}_{2}$ and $\mathrm{ZrCr}_{2}$ (Fig. 3).

The analysis presented in Fig. 1 - Fig. 3 of binary and ternary state diagrams indicates the possibility of formation under equilibrium conditions of carbide phases of various composition and Laves phases. It should be expected that ultrahigh cooling rates of the material initiated by irradiation with an intense pulsed electron beam of the system "film (alloy Zr-Ti-Cu) / (steel AISI420) substrate" will have a significant effect on phase transformations of the material.

The elemental composition of the surface layer of the modified steel was studied using methods of micro-X-ray spectral analysis. It has been established that the relative content of chromium in the surface layer of the irradiated system "film (Zr-Ti$\mathrm{Cu}$ alloy) / (AISI420 steel) substrate", regardless of the energy density of the electron beam, varies from 12.5 wt. $\%$ to 13.1 wt. $\%$, which is close to chromium content in the initial material. The relative content of zirconium decreases from 2.0 at $\%$ to 0.6 atomic $\%$ as the energy density of the electron beam increases from $20 \mathrm{~J} / \mathrm{cm}^{2}$ to $40 \mathrm{~J} / \mathrm{cm}^{2}$. A decrease in the concentration of zirconium evidently indicates the diffusion of zirconium atoms into the volume of steel, i.e. formation of the surface alloy upon the irradiation of the system "film (Zr-Ti-Cu alloy) / (AISI420 steel) substrate" with an intense pulsed electron beam.

The phase composition and the defective substructure of the surface layer formed upon the irradiation of the system "film (Zr-Ti-Cu alloy) / (AISI420 steel) substrate" with an intense pulsed electron beam were studied using methods of transmission electron diffraction microscopy. It has been established that steel doping with elements of the film $(\mathrm{Zr}-\mathrm{Ti}-\mathrm{Cu})$ leads to formation of a polycrystalline structure based on $\alpha$-iron in the surface layer, irrespective of the electron beam irradiation parameters (Fig. 2, a). The grain substructure is represented by high crystallization cells (Fig. 4). The average size of crystallization cells significantly depends on the irradiation parameter and increases from $150 \mathrm{~nm}$ at $E_{\mathrm{S}}=20 \mathrm{~J} / \mathrm{cm}^{2}$ to $370 \mathrm{~nm}$ at $E_{S}=40 \mathrm{~J} / \mathrm{cm}^{2}$. It is obvious that the reason for the growth of crystallization cells is a decrease in the cooling rate of the material with an increase in the energy density of the electron beam. The volume of crystallization cells contains a dislocation substructure in the form of chaotically distributed dislocations (Fig. 4, b).

Particles of the second phase are located along the boundaries of cells, rarely in the volume of cells. The particles have a round shape, and their particle size varies from 15 to $35 \mathrm{~nm}$. Indication of microelectronograms shows that these particles are zirconium carbide (Fig. 5). In rare cases, particles of a complex carbide of the type $\mathrm{M}_{23} \mathrm{C}_{6}$ are found in the structure of the surface layer of steel. 


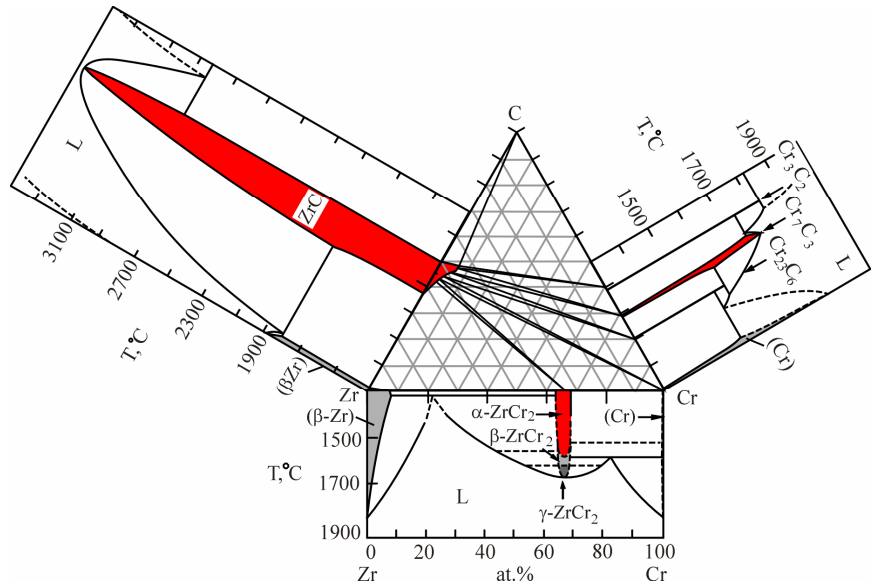

Figure 1. State diagrams of systems $\mathrm{C}-\mathrm{Zr}, \mathrm{C}-\mathrm{Cr}, \mathrm{Cr}-\mathrm{Zr}$ and the isothermal section of the ternary system $\mathrm{Zr}-\mathrm{Cr}-\mathrm{C}$ at a temperature of $1300^{\circ} \mathrm{C}[16]$



Figure 2. State diagrams of systems $\mathrm{C}-\mathrm{Zr}, \mathrm{C}-\mathrm{Fe}, \mathrm{Fe}-\mathrm{Zr}$ and the isothermal section of the ternary system $\mathrm{Zr}-\mathrm{Fe}-\mathrm{C}$ at a temperature of $900{ }^{\circ} \mathrm{C}[17]$ 




Figure 3. Binary diagrams of systems $\mathrm{Cr}-\mathrm{Fe}, \mathrm{Zr}-\mathrm{Cr}, \mathrm{Fe}-\mathrm{Zr}$ [18] and the isothermal cross section of the ternary system $\mathrm{Cr}-\mathrm{Fe}-\mathrm{Zr}$ at a temperature of $\mathrm{T}=800{ }^{\circ} \mathrm{C}[19]$
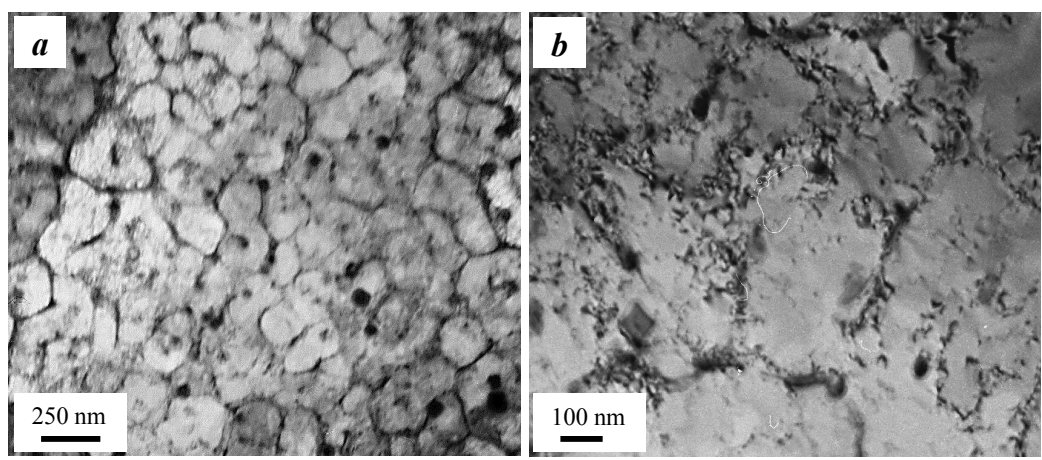

Figure 4. Electron microscopic image of the surface layer structure of the system "film (Zr-Ti-Cu alloy) / (AISI420 steel) substrate", subjected to irradiation with an intense pulsed electron beam $\left(18 \mathrm{keV}, 40 \mathrm{~J} / \mathrm{cm}^{2}\right.$, 200 microseconds, 3 pulses; $0,3 \mathrm{~s}^{-1}$ ). 


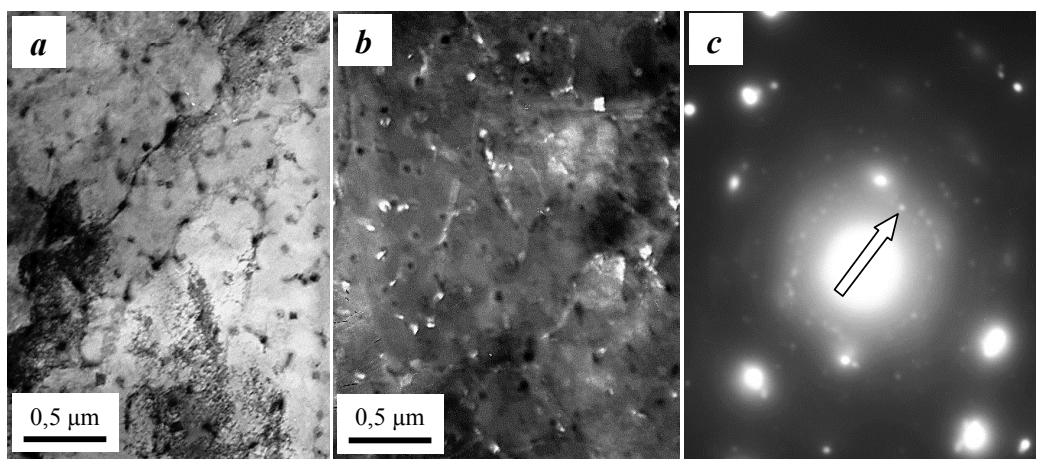

Figure 5. Electron microscopic image of the structure of the surface layer of the system "film ( $\mathrm{Zr}-\mathrm{Ti}-\mathrm{Cu}$ alloy) / (AISI420 steel) substrate" subjected to irradiation with an intense pulsed electron beam $(18 \mathrm{keV}, 30$ $\mathrm{J} / \mathrm{cm}^{2}, 200$ microseconds, 3 pulses; $\left.0,3 \mathrm{~s}^{1}\right) ; a$ is the bright field; $b$ is the dark field obtained in the reflex [002] $\mathrm{ZrC} ; c$ is the microelectronogram (the arrow indicate the reflex in which the dark field is obtained).

Analyzing the results obtained in the study of the system "film (Zr-Ti-Cu alloy) / (20X13 steel) substrate" using methods of diffraction electron microscopy and the results in Fig. 1 and Fig. 3, it can be stated that ultra-high cooling rates, occurring in the process of material treatment with an intense pulsed electron beam, allow to form only carbide phases in the surface layer of the material, i.e. phases, one of whose elements (namely carbon) possesses high mobility in steel. The carried out studies did not reveal any compounds of the intermetallic type.

\section{Conclusion}

It has been shown that irradiation of the system "film (alloy Zr-Ti-Cu) / (AISI420 steel) substrate" with an intensive pulsed electron beam is accompanied with the following: formation of a surface alloy, whose concentration of doping elements $(\mathrm{Zr})$ decreases with an increase in the energy density of the electron beam; formation of a cellular crystallization structure; decomposition of a solid solution with a release of zirconium carbide and chromium carbides particles.

The analysis of transformation phase diagrams occurring under equilibrium conditions in systems $\mathrm{Fe}-\mathrm{Zr}-\mathrm{C}$; $\mathrm{Cr}-\mathrm{Zr}-\mathrm{C}$; Fe-Cr-Zr has been carried out. It has been established that ultra-high cooling rates, taking place during the irradiation of the system "film (alloy Zr-Ti-Cu) / (AISI420 steel) substrate" with an intense pulsed electron beam, impose certain restrictions on phase formation in these systems. Methods of diffraction electron microscopy have allowed to reveal formation of predominantly carbide phases in the surface layer (i.e. phases, one of whose elements (namely carbon) possesses high mobility in steel). The carried out studies did not reveal any compounds of the intermetallic type.

\section{Acknowledgement}

This work was supported by Russian Foundation for Basic Research (project number 16-43-700659-p).

\section{References}

1. Poate J., Foti G., Jacobson D. Surface modification and alloying: by laser, ion and electron beams. Moscow: Mashinostroeniye, 1987, 424 p. (In Russ.)

2. Andriyakhin V.M., Fishkis M.M. Lazery i perspektivy ikh primeneniya $v$ avtomobilestroenii [Lasers and prospects of their application in the automotive industry]. Moscow: NII Avtoprom, 1980, 40 p. (In Russ.)

3. Belov A.B., Bytsenko O.A., Krainikov A.V. et al. Silnotochnye impulsnye elektronnye puchki dlya aviatsionnogo dvigatelestroeniya [High-current pulsed electron beams for aircraft engine building]. Ed. by Novikov A.S., Shulov V.A., Engelko V.I. Moscow: Dipak, 2012, 292 p. (In Russ.)

4. Bugaev S.P., Kreindel Yu.E., Shchanin P.M. Elektronnye puchki bolshogo secheniya [Electronic beams of large cross section]. Moscow: Energoatomizdat, 1984, 113 p. (In Russ.)

5. Koval N.N., Oks E.M., Protasov Yu.S., Semashko N.N. Emissionnaya elektronika [Emission electronics]. Moscow: BMSTU Publishing House, 2009, 596 p. (In Russ.)

6. Goebel D.M., Schumacher R.W. Long pulse plasma cathode e-gun. Ed. by R.M. Watkins. Proc. SPIE, 2001, pp. 1093-1098.

7. Remnev G.E., Isakov I.F., Opekunov M.S. et al. High intensity pulsed ion beam sources and their industrial applications. Surface and Coatings Technology, 1999, vol.114, pp. 206-212.

8. Uglov V.V., Cherenda N.N., Anishchik V.M., Astashinsky V.M., Kvasov N.T. Modifikatsiya materialov kompressionnymi plazmennymi potokami [Modification of materials by compression plasma flows]. Minsk: BSU, 2013, 248 p. (In Russ.)

9. Tyurin Yu.N., Zhadkevich M.L. Plazmennye uprochnyayushchie tekhnologii [Plasma strengthening technologies]. Kiev: Naukova Dumka, 2008, 216 p. (In Russ.)

10. Gribkov V.A., Grigoriev F.I., Kalin B.A. et al. Perspektivnye radiatsionno-puchkovye tekhnologii obrabotki metallov 
[Prospective radiation-beam technologies for metal processing]. Moscow: Krugliy stol, 2001, 528 p. (In Russ.)

11. Kadyrzhanov K.K., Komarov F.F., Pogrebnyak A.D. et al. lonno-luchevaya i ionno-plazmennaya modifikatsiya materialov [lon-beam and ion-plasma modification of materials]. Moscow: MSU Publishing House, 2005, 640 p. (In Russ.)

12. Barvinok V.A., Bogdanovich V.I. Fizicheskie osnovy $i$ matematicheskoe modelirovanie protsessov vakuumnogo ionnoplazmennogo napyleniya [Physical basis and mathematical modeling of the processes of vacuum ion-plasma spraying]. Moscow: Mashinostroeniye, 1999, 309 p. (In Russ.)

13. Andreev A.A., Sablev L.P., Shulaev V.M., Grigoriev S.N. Vakuumno-dugovye ustroystva i pokrytiya (Vacuum-arc devices and coatings]. Kharkov: NSC KIPT, 2005, 236 p. (In Russ.)

14. Sorokin V.G., Volosnikova A.V., Vyatkin S.A. et al. Marochnik staley $i$ splavov [Grade guide of steels and alloys]. Ed. by So- rokin V.G. Moscow: Mashinostroeniye, 1989, 640 p. (In Russ.)

15. Ivanov Yu.F., Krysina O.V., Petrikova E.A., Teresov A.D., Shugurov V.V., Tolkachev O.S. Complex electron-ion plasma treatment of titanium: methods, structure, properties. J. High Temp. Mater. Proc. 21(1) (2017), pp. 53-64.

16. Halleck H. Dvoynye i troynye karbidnye i nitridnye sistemy perekhodnykh metallov [Double and triple carbide and nitride systems of transition metals]. Moscow: Metallurgiya, 1988, 319 p. (In Russ.)

17. M. Jiang, K. Oikawa, T. Ikeshoji, L. Wulff, K. Ishida. J. Phase Eq. 4 (2001) 406-17.

18. Lakishev N.P. Diagrammy sostoyaniya dvoynykh metallicheskikh system [State diagrams of binary metal systems]. Moscow: Mashinostroenie, 1996-2000, vol. 1-3. (In Russ.)

19. Malakhova T.O., J. Alloys At. Energ. (1979) 123-130.

Received 12/02/18

Accepted 16/04/18

ИНФОРМАЦИЯ О СТАТЬЕ НА РУССКОМ

УДК 533.9:539.4.015.2

https://doi.org/10.18503/1995-2732-2019-17-1-58-63

\title{
ВЛИЯНИЕ СКОРОСТИ ОХЛАЖДЕНИЯ НА ФАЗОВЫЕ ПРЕВРАЩЕНИЯ В ПОВЕРХНОСТНО ЛЕГИРОВАННОМ СЛОЕ СТАЛИ
}

\author{
Иванов Ю.Ф. ${ }^{1}$, Клопотов А.А. ${ }^{2}$, Тересов А.Д. ${ }^{1}$, Петрикова Е.А. ${ }^{1}$, Шугуров В.В. ${ }^{1}$, Сонг $\Gamma^{3}$, Танг Г. ${ }^{3}$, Громов В.Е. ${ }^{4}$ \\ ${ }^{1}$ Институт сильноточной электроники СО РАН, Томск, Россия \\ ${ }^{2}$ Томский государственный архитектурно-строительный университет, Томск, Россия \\ ${ }^{3}$ Университет цинхуа, Шэньчжэнь, Китай \\ ${ }^{4}$ Сибирский государственный индустриальный университет, Новокузнецк, Россия
}

Аннотация. В едином вакуумном цикле осуществлено поверхностное легирование стали AISI420, заключающееся в напылении тонкой (0,5 мкм) пленки сплава $\mathrm{Zr}-\mathrm{Ti}-\mathrm{Cu}$ электродуговым распылением катода состава $\mathrm{Zr}-6$ ат.\% Ті-6 ат.\% Сu и последующем облучении системы «пленка (сплав Zr-Ti-Cu) / (сталь AISI420) подложка» интенсивным импульсным электронным пучком. Показано, что с ростом плотности энергии пучка электронов $\left(\mathrm{E}_{\mathrm{S}}\right)$ концентрации циркония в поверхностно слое стали снижается. Установлено, что формирование поверхностного сплава сопровождается, во-первых, образованием структуры ячеистой кристаллизации (средний размер ячеек увеличиваются от 150 нм при $\mathrm{E}_{\mathrm{S}}$

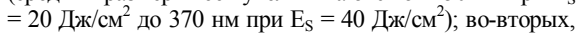
протеканием распада твердого раствора с выделением частиц карбида циркония (размеры частиц увеличива-



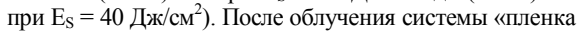
(сплав Zr-Ti-Cu) / (сталь AISI420) подложка» интенсив- ным импульсным электронным пучком $\left(\mathrm{E}_{\mathrm{S}}=40\right.$ Дж/ $\mathrm{cm}^{2}$ ) наряду с частицами карбида циркония выявляются частицы карбидной фазы на основе хрома состава $\mathrm{Cr}_{3} \mathrm{C}_{2}, \mathrm{Cr}_{7} \mathrm{C}_{3}$ и $(\mathrm{Cr}, \mathrm{Fe})_{23} \mathrm{C}_{6}$. Частицы карбидов хрома имеют округлую форму, размеры их изменяются в пределах от 40 до 60 нм. Выполнен анализ фазовых диаграмм превращений, протекающих в равновесных условиях в системах $\mathrm{Fe}-\mathrm{Zr}-\mathrm{C}$; $\mathrm{Cr}-\mathrm{Zr}-\mathrm{C}$; Fe-Cr-Zr. Установлено, что сверхвысокие скорости охлаждения, реализующиеся при облучении системы «пленка (сплав $\mathrm{Zr}-\mathrm{Ti}-\mathrm{Cu}$ ) / (сталь AISI420) подложка» интенсивным импульсным электронным пучком, накладывают ограничения на образование фаз интерметаллидного типа. Высказано предположение, что формирование в поверхностном слое материала преимущественно карбидных фаз обусловлено высокой подвижностью в стали атомов углерода.

Ключевые слова: сталь AISI-420, электроннопучковая обработка, структура, фазовый состав.

Поступила 12.02.18

Принята в печать 16.04 .18

Образец для цитирования

Ivanov Yu., Klopotov A., Teresov A., Petrikova E., Shugurov V., Song G., Tang G., Gromov V. Effect of the cooling rate on phase transformations in a surface-alloyed layer of steel // Вестник Магнитогорского государственного технического университета им. Г.И. Носова. 2019. T.17. №1. C. 58-63. https://doi.org/10.18503/1995-2732-2019-17-1-58-63

For citation

Ivanov Yu., Klopotov A., Teresov A., Petrikova E., Shugurov V., Song G., Tang G., Gromov V. Effect of the cooling rate on phase transformations in a surface-alloyed layer of steel. Vestnik Magnitogorskogo Gosudarstvennogo Tekhnicheskogo Universiteta im. G.I. Nosova [Vestnik of Nosov Magnitogorsk State Technical University]. 2019, vol. 17, no. 1, pp. 58-63. https://doi.org/10.18503/1995-2732-2019-17-1-58-63 